\title{
On the Structure of the Palaeozoic Seed Mitrospermum compressum (Will.).
}

\author{
BY
}

\author{
AGNES ARBER, D.Sc., F.L.S.
}

With Plates XXXVII-XXXIX, and two Figures in the Text.

\section{Contents.}

I. INTRODUCTION -

II. General Characters of the Seed :
A. The Sclerotesta. . . . . . . . . . 492

B. The Sarcotesta . . . . . . . . . 495

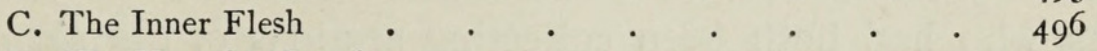

D. The Vascular Supply . . . . . . 497

E. The Nucellus and Embryo-Sac . . . . . . 497

III. Histological Details :
A. The Sclerotesta .
B. The Sarcotesta . . . . . . . . . 499
C. The Seed-Base . . . . . . . . . 500
D. The Vascular Tissue . . . . . . . . $50 \mathrm{I}$

IV. Nomenclature :

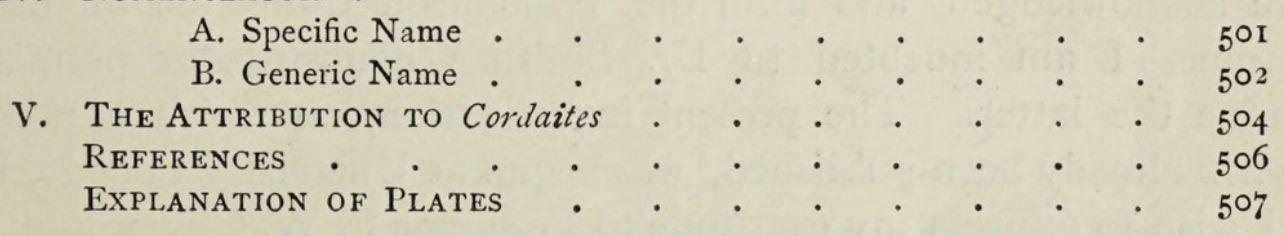

I. IntRODUCTION.

$7 \mathrm{HE}$ numerous fossil seeds occurring in the Palaeozoic rocks have been 1 conveniently grouped by Oliver ${ }^{1}$ under the names Platyspermeae and Radiospermeae, these names corresponding to the two series originally distinguished by Brongniart. ${ }^{2}$ As the words imply, the Platyspermeae are flattened seeds with a bilateral symmetry, while the Radiospermeae are radially symmetrical. Our knowledge of the internal structure of the Radiosperms has of late years progressed very rapidly. To realize this we need only recall the memoirs on Lagenostoma Lomaxi, ${ }^{3}$ Stephanospermum, ${ }^{4}$ Trigonocarpus, ${ }^{5}$ and Physostoma, ${ }^{6}$ which all fall within half

1 Oliver ('03).

4 Oliver ('04).
${ }^{2}$ Brongniart ('74).

${ }^{5}$ Scott and Maslen ('07).
${ }^{3}$ Oliver and Scott ('04).

${ }^{6}$ Oliver ('09).

[Annals of Botany, Vol. XXIV. No. XCV. July, Igro.] 


\section{Agnes Arber.-On the Structure of the Palaeozoic Seed}

a decade. In the case of the Platysperms less progress has been made. A number of these seeds, occurring in the silicified pebbles from the French Upper Palaeozoic rocks, were long ago described by Brongniart, ${ }^{1}$ and subsequently figured. ${ }^{2}$ Quite recently Bertrand ${ }^{3}$ has revised Brongniart's work, in the light of Renault's preparations, and has amended the generic and specific diagnoses. Williamson, ${ }^{4}$ working about the same time as Brongniart, contributed a description and figures of a flattened seed from the British Carboniferous rocks, which he named Cardiocarpon compressum. His description was necessarily incomplete owing to the fact that he had very few specimens, and that his more important sections were not thin enough to reveal the detailed structure. Since Williamson's paper was published, no further advance seems to have been made in our knowledge of the internal structure of British Platysperms.

Seeds similar to those figured by Williamson under the name of Cardiocarpon compressum occasionally occur in, sections of the English Lower Coal Measure nodules, or 'coal-balls'. Professor F. W. Oliver, who had formed a collection of such preparations, suggested to me that I should undertake their examination. I am also indebted to Dr. Scott and Professor Weiss, who had both been collecting sections of Cardiocarpon compressum with a view to their ultimate description, and who very generously made over to me the whole of their material. Miss Benson and Mr. D. M. S. Watson have also been so good as to lend me sections which have been of great value. The following account is based mainly on the preparations in the University College Collection, supplemented by those from the sources above acknowledged, and from the Williamson Collection in the British Museum. I am indebted to Dr. Smith Woodward for permission to examine the latter. The present investigation, on which a preliminary note has already been published, ${ }^{5}$ was begun at University College, London, and I wish to express my gratitude to Professor F. W. Oliver, under whose direction it was undertaken. I have also to thank Dr. Scott for his help and advice in connexion with the study.

In the present paper I propose to use the new generic name Mitrospermum in lieu of Cardiocarpon for the seed under discussion. The reasons for this change will be deferred until the structure has been considered. ${ }^{6}$

\section{General Characters of the Seed.}

\section{A. The Sclerotesta.}

The seed is a characteristic Platysperm. It is symmetrical about two planes. The first is the plane of flattening, or in other words the plane which traverses the longer axis of the transverse section (Text-Fig. 2, C, p.p.).

1 Brongniart ('74). $\quad{ }^{2}$ Brongniart ('81).

4 Williamson ('77).
5 Agnes Arber ('10).
${ }^{8}$ Bertrand ('07 and '08).

${ }^{6}$ See p. $5^{\circ 2}$. 
This is called by Bertrand ${ }^{1}$ the 'antéro-postérieur' or 'A $\mathrm{P}$ ' plane, but it is more generally known as the principal plane ${ }^{2}$ of the seed. The second plane of symmetry is named by Bertrand the ' gauche-droite ' or ' GD' plane, but no convenient English term is in use for it. As it is often necessary to refer to it, I propose to call it the secondary plane. It lies at right angles to the principal plane, and traverses the shorter axis of the transverse section (Text-Fig. $2 \mathrm{C}, s . p$.).

The flattened sclerotesta or shell is about $5 \mathrm{~mm}$., both in length and breadth, or sometimes more. It is pointed above and broadest near the base. The form is shown in Text-Fig. I, A, and Pl. XXXVII, Fig. 9, where the seed is represented cut approximately in the principal plane. Median sections in the secondary plane show an outline broadest towards the base and tapering to the micropyle (Text-Fig. I, B).

There are some indications which suggest that the valves ultimately separated in the principal plane of the seed, but there are no sharply defined dehiscence planes, comparable with those found in such a seed as Diplotesta. ${ }^{3}$ In the section photographed in Pl. XXXVII, Fig. 4, a stigmarian rootlet has wedged itself into the shell, which has given way at the junction of the valves.

In the centre of the seed-base a small space is left between the valves, forming a basal foramen. Each valve of the shell had a slight, external, angular ridge in the median plane, extending upwards from the base, but dying out in the upper part of the seed (Text-Fig. 2, C, $r$, and Pl. XXXVII, Fig. 10, $r$ ). The disappearance of the ridge in the upper region of the shell can be traced in a series of five transverse sections ${ }^{4}$ cut from one seed by Miss Benson.

At the chalaza, inside the shell, a slightly raised cushion of tissue projects from the floor into the cavity of the seed, occupying the whole width of the seed in the secondary plane, but only part of the width in the principal plane. This projection, which consists mainly of the expanded upper extremity of the main supply bundle, ${ }^{5}$ seems to correspond to the structure which Bertrand, ${ }^{6}$ in describing other cases, has named a 'crête sous-chalazienne'. As the projection occupies only part of the width of the seed, a slight sinus is left on each side, so that the form of the whole seed cavityapproaches a heart-shape. Williamson ${ }^{7}$ figures a section across a seed at the level of the sinuses. The somewhat oblique, transverse section shown in PI. XXXVII, Fig. IO, of the present paper, passes through a sinus on one side, but dips into the basal wall on the other side. The sinuses must have been very shallow, and a section cut precisely in the principal plane would be needed to expose them in profile. The sections represented in Pl. XXXVII,

1 Bertrand ('07 and '08).

2 Oliver ('03).

${ }^{3}$ Bertrand $\left({ }^{\prime} 07^{2}\right)$.

${ }^{4}$ Royal Holloway College Collection, 35I $(7-\mathrm{II})$.

${ }^{5}$ See p. 497 .

${ }^{6}$ e.g. Bertrand $\left({ }^{4} 07^{2}\right)$.

${ }^{7}$ Williamson ('77), Pl, XV, Fig. I24. 
Fig. 9, and P1. XXXIX, Fig. 26, are by no means accurately median, and hence the sinuses can hardly be detected.

The valves of the shell are slightly thickened at the base of the micropylar canal (Text-Fig. I, B, and Pl. XXXVII, Fig. 2 ; cf. also Williamson's ${ }^{1}$ Fig. 126). The canal is diamond-shaped in section, the longer axis lying in the principal plane (Text-Fig. 2, A). The valves rapidly taper upwards, becoming very thin at the actual orifice (Pl. XXXVII, Figs. 2 and 3 ).

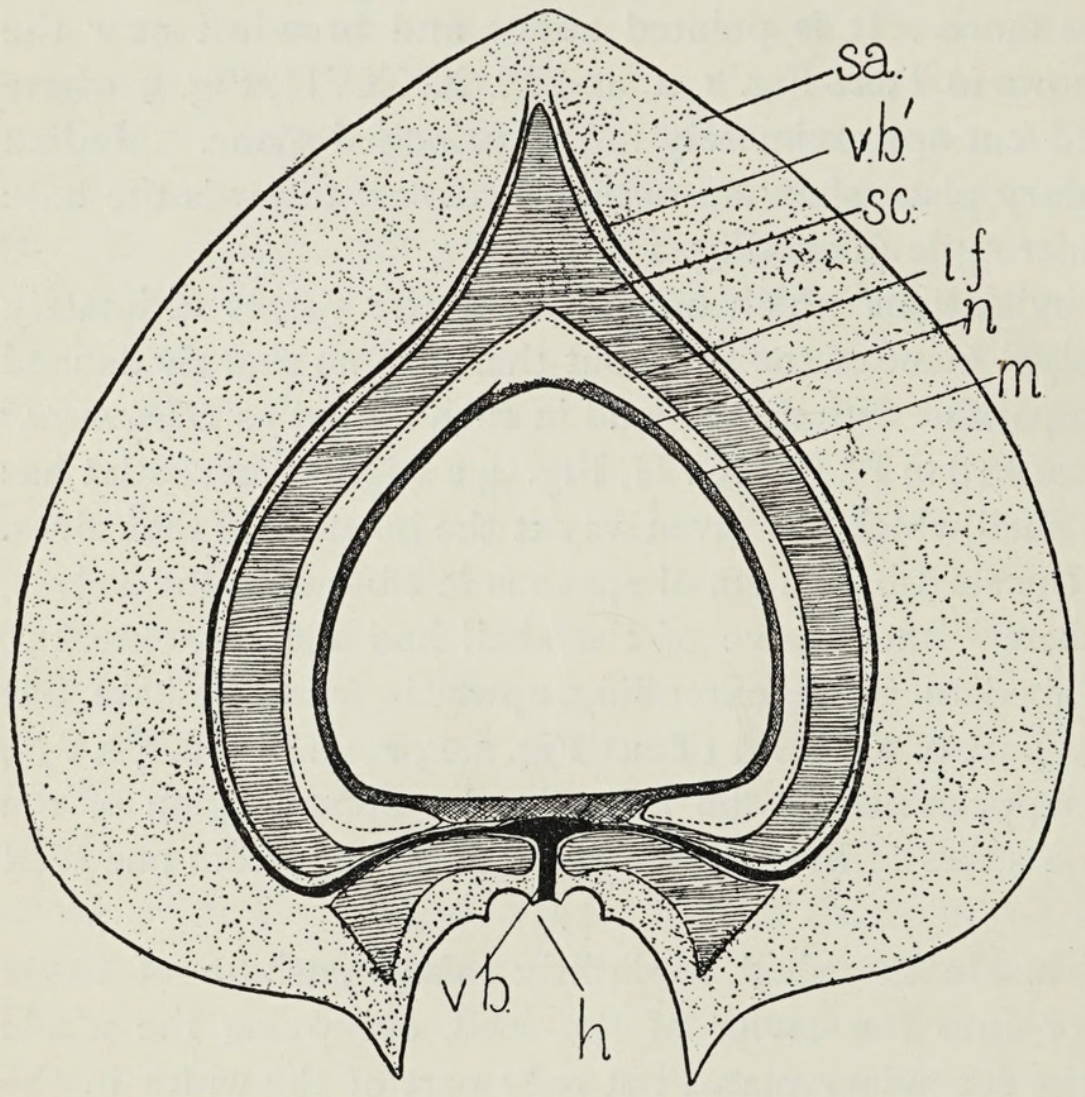

A

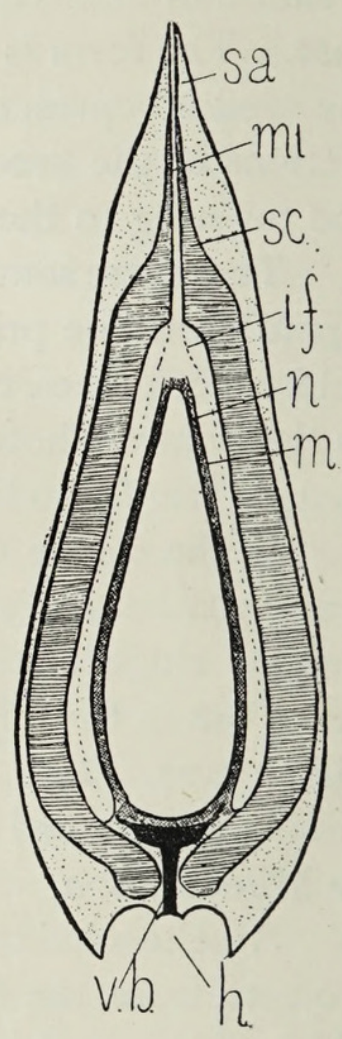

B

TEXT-Figure I, A and в. Diagrammatic restoration of longitudinal sections of Mitrospermum compressum (Will.) ( $\times 8$ or 9 ). $\mathrm{A}$ is cut in the principal plane; $\mathrm{B}$ in the secondary plane. (The apex of the nucellus is left incomplete, because no sections have been met with in which the pollenchamber is clearly exposed. The form of the downward projections of the sclerotesta base in A is slightly uncertain.) $s a .=$ sarcotesta $; s c_{0}=$ sclerotesta $; m i .=$ micropyle $; i f .=$ inner flesh ; $n .=$ nucellus $; m .=$ megaspore $; v \cdot b .=$ main vascular bundle; $v \cdot b^{\prime} .=$ branch vascular bundle; $h$. $=$ hilum.

Figs. 7 and 8, Pl. XXXVII, are photographs of two specimens in the Williamson Collection, ${ }^{2}$ which may represent shells, or casts of the shellcavities, of seeds nearly allied to Mitrospermum.

1 Williamson ('77).

2 Williamson describes these specimens in his MS. catalogue as follows :- ' 1427 . Possibly a nucleus of some of the Sammaropsid forms of Lesquereux. Little Hutton near Peel, Delph, Lancashire. Mr. Wm. Monkhouse.' 


\section{B. The Sarcotesta.}

In the better preserved specimens the shell is enclosed in a delicate sarcotesta. This takes the form of a thin layer of tissue clothing the surfaces of the valves, and at their lateral edges extending beyond them as a wing or flange lying in the principal plane. Sections of the apex of the seed, which pass through both shell and sarcotesta exactly in the plane of flattening, would be needed in order to demonstrate definitely the contour of the wing at the micropylar end. Such sections have not been found, but it is probable that the outline in this plane resembled that diagrammatically shown in Text-

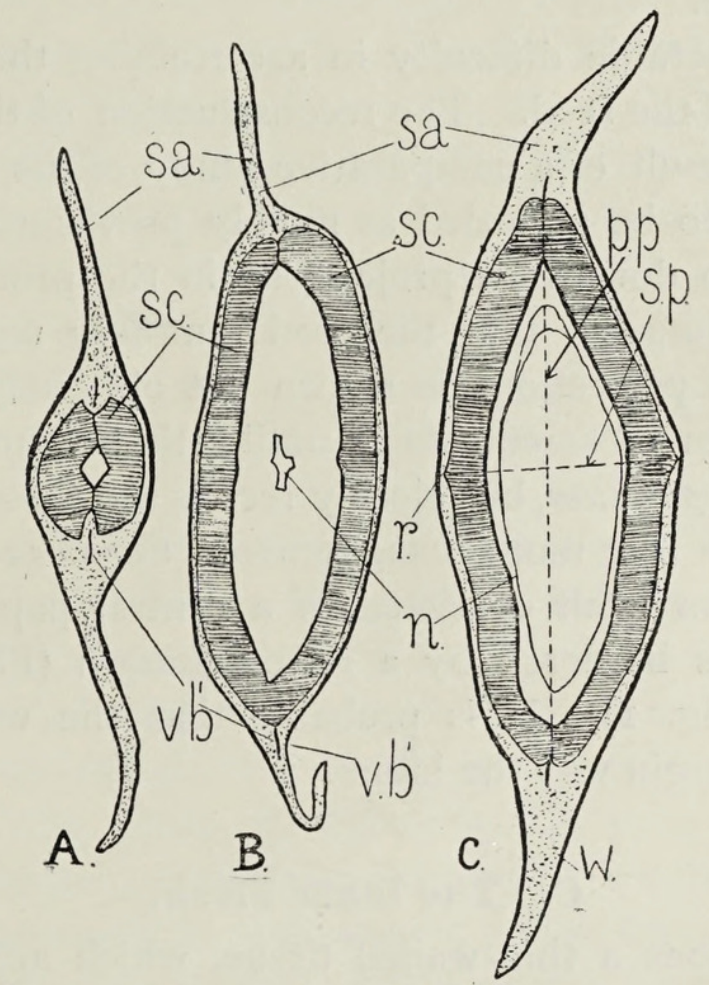

TEXT-FIgURE 2, A, B, and C. Diagrammatic (slightly restored) transverse sections of Mitrosfermum compressum (Will.) ( $\times 8$ or 9 ). $\mathbf{A}$ and $\mathrm{B}$ are sections from the same seed (slides 1693 and 1694, in Dr. Scott's Collection; from Dulesgate). A is nearer the apex than B. C is a section of another seed nearer the base than either A or B (Slide I4I7, in the Williamson Collection, named in Williamson's manuscript catalogue Cardiocarpon anomalum). $s a .=$ sarcotesta; $s c .=$ sclerotesta $; n .=$ nucellus $; v \cdot b^{\prime} .=$ branch vascular bundle; $w_{0}=$ wing $; p \cdot p \cdot=$ principal plane $; s . p .=$ secondary plane $; r_{0}=$ median ridge of sclerotesta.

Fig. I, A. Transverse sections, which seem from internal evidence to have been cut near the micropyle, show a greater breadth of wing in proportion to the shell than sections taken lower down (cf. Text-Fig. 2, A and C).

A seed with the sarcotesta preserved, cut through the micropyle in a plane at right angles to the plane of flattening (i. e. in the secondary plane), fortunately occurs in the University College Collection (P1. XXXVII, Fig. 2). It is clear, from this specimen, that the sarcotesta became much thicker at the level at which the shell began to taper off to the micropylar orifice. The micropyle seems to have been of considerable length, and in the upper 
part its wall consisted chiefly, if not entirely, of sarcotestal tissue. It is impossible to decide exactly where the shell terminated. Judging from the single section now under discussion, we may say that, roughly, the lower third of the micropylar canal was bounded by the thick but tapering upper region of the shell, the middle third by a prolongation of the shell as a thin stiffening membrane, and the upper third by the sarcotesta alone. The preservation of the section, however, is imperfect, and further specimens cut in this plane are needed before we can arrive at a final interpretation. It is possible that this section may belong to a different, though closely related, species, since both the sarcotesta and 'inner flesh ' ${ }^{1}$ are developed to an unusual degree.

There is considerable difficulty in ascertaining the form of the sarcotesta at the base of the seed. The reconstruction of this region shown in Text-Fig. I is the result of a comparative study of the sections at present available, but it is to be regarded as merely provisional. It appears that the wing formed two downward projections in the principal plane, one on each side of the hilum, so that the seed remotely resembled a mitre in shape. One of the projections is shown cut obliquely in Pl. XXXVII, Fig. 5. Such a form of sarcotesta is unlike that figured by Williamson ${ }^{2}$ for Cardiocarpon compressum, but closely recalls the Cardiocarpon anomalum of Carruthers, ${ }^{3}$ and the more exaggerated Cardiocarpus bicandatus of Kidston. ${ }^{4}$ The hilum itself consisted of a central papilla, surrounded by a groove, which was bordered by a raised margin (Pl. XXXVII, Figs. 5 and 6 , and Text-Fig. I). It is probable that the whole area included within the raised margin was the hilum.

\section{The Inner Flesh.}

In certain sections a thin-walled tissue, which apparently belongs to the integument, is preserved within the shell. It may be called the 'inner flesh', since Scott and Maslen ${ }^{5}$ have used this term for a similar tissue occurring in Trigonocarpus, on account of its correspondence in position with the inner flesh of a Cycad seed. Fig. 2, Pl. XXXVII, which is a photograph of a longitudinal section cut in the secondary plane, shows a considerable development of the inner flesh. In another section ${ }^{6}$ resembling this one, but cut a little to one side of the median plane, we find the inner flesh well developed between the nucellus and the base of the shell. This tissue is also seen in a transverse section ${ }^{7}$ in Dr. Scott's Collection. Altogether the manner of occurrence of the 'inner flesh' suggests that it originally formed a continuous lining to each valve, but that it has only been occasionally preserved. The reason for its frequent absence may perhaps be the same

\footnotetext{
1 See below.

${ }^{3}$ Carruthers ('72), Fig. 3 .

${ }^{5}$ Scott and Maslen ('07), p. IIO.
}

${ }^{2}$ Williamson ('77), Fig. I 2 I.

${ }^{4}$ Kidston ('94), Pl. VI, Fig. 3.

${ }^{6}$ U. C. L., S. 68.

${ }^{7}$ D. H. S. $2275^{\circ}$ 
as that suggested by Scott and Maslen ${ }^{1}$ to explain the disappearance of the inner flesh in Trigonocarpus, namely, 'that the cells themselves were of a delicate nature, and also that the hard impermeable coat of the seed prevented the infiltration of the petrifying material before the tissue had undergone disorganization'.

The inner flesh seems to correspond to the 'plaques tylaires' described by Bertrand ${ }^{2}$ as characteristic of the species of Cardiocarpus found in the French Carboniferous rocks.

\section{The Vascular Supply.}

A vascular bundle (v.b. in Text-Fig. 1 ) enters the hilum, and passes straight up to the base of the nucellus, through the foramen in the shell to which we have already referred. Below the nucellus, the end of the bundle expands, and gives off two opposite branches lying in the principal plane of the seed. These strands are at first almost horizontal, but they soon bend downwards and outwards, traversing the shell in an oblique direction (Pl. XXXVII, Fig. 9, and P1. XXXIX, Fig. 26). On emerging into the sarcotesta they curve upwards, and pass towards the micropyle, following the slight groove at the junction of the valves. We may infer that the bundles continued through almost the whole length of the seed, since they can be followed in transverse and longitudinal sections as far as the base of the micropyle, and tracheides have even in one case ${ }^{3}$ been recognized close to the upper part of the micropylar canal.

A small number of tracheides are given off from the expanded end of the central bundle, not far above its two main branches, mostly in the plane at right angles to the plane of flattening. Median sections, cut in the secondary plane, expose these tracheides running longitudinally to right and left at the base of the nucellus, and forming a thin, horizontal, tracheal plate. I have not been able definitely to satisfy myself as to whether a nucellar vascular system arises from this tracheal plate. The nucellus as a rule survives only as a carbonized layer showing but little structure, though in certain of the sections in which it is better preserved, ${ }^{4}$ elongated elements with indications of tracheal markings can be detected at various levels. It is possible that these elements may prove to be vascular.

\section{E. The Nucellus and Embryo-Sac.}

The nucellus seems to have been free from the integument from its base upwards, as in Stephanospermum ${ }^{5}$ and Trigonocarpus. ${ }^{6}$ The possibility that an appearance of freedom might be due to a contraction and tearing of the nucellar tissues must not be overlooked. There seems, how-

\footnotetext{
1 Scott and Maslen ('07), p. I Io.

${ }^{2}$ Bertrand ('08²).

${ }^{3}$ U. C. L., S. 7o. Cf. also D. H. S. 2254 and U. C. L., S. 35 .

${ }^{4}$ e.g. U. C. L., S. 36, S. 53 , S. 68 , S. 69.

${ }^{5}$ Oliver ('04).

${ }^{6}$ Scott and Maslen ('07).
} 


\section{Agnes Arber.-On the Structure of the Palaeozoic Seed}

ever, little reason to doubt that in Mitrospermum compressum the space between integument and nucellus was natural and not artificial.

In the upper part of the seed the nucellus, as seen in transverse section, is characterized by four salient angles, which lie in the principal plane and the plane perpendicular to it (Pl. XXXVIII, Figs. I7 and I9). It has been already mentioned that near the micropyle the shell cavity becomes diamondshaped in section. It is probable that this fact explains the four-angled form of the nucellus, since in the living seed it must have fitted the shell cavity fairly closely. The shrinking of the softer tissues, due to fossilization, has, however, caused the angled part of the nucellus to be drawn down to a level below that of the corresponding angled part of the shell-cavity.

There is, unfortunately, no case known in Mitrospermum compressum of a typical, well-preserved pollen-chamber at the apex of the nucellus, but a preparation in the University College Collection (Pl. XXXVIII, Fig. 2I) recalls one of Scott and Maslen's figures of an oblique longitudinal section of Trigonocarpus Oliveri, ${ }^{\text {' }}$ in which the pollen-chamber ' is apparently cut through'. The marked 'shoulders' of the nucellus in this preparation of Mitrospermum compressum also recall certain figures given by Brongniart ${ }^{2}$ of Cardiocarpus sclerotesta and C. tenuis. In Mr. Watson's Collection there is an interesting transverse section, which seems to pass through the pollenchamber (P1. XXXVIII, Figs. I7 and 18). The section of the nucellus is very small and almost square. Elongated cells radiate from a tiny space in the centre. If we imagine that the pollen-chamber was of the type found in Cordaianthus Grand'Euryi, ${ }^{3}$ a section such as the one under consideration might be explained as cutting through the pollen-chamber at the base of the beak. Renault describes the wall of the pollen-canal in this species as formed of cells elongated in the transverse direction, and radiating round the central conduit.

The megaspore and the narrow nucellus are as a rule much shrivelled and carbonized, but the most favourable sections indicate that the megaspore was surrounded by a nucellar tapetum. This is often preserved only as a structureless line. On the outer side of the tapetum, there are a few layers of thin-walled cells, among which, as has already been stated, there are occasional traces of elements which may have been tracheal in nature. This delicate tissue is clothed externally by a carbonized nucellar epidermis (Pl. XXXVIII, Figs. 22 and 23).

A seed of which there are two sections in Dr. Scott's Collection ${ }^{4}$ has a tissue within the embryo-sac, which may be a prothallus (PI. XXXIX, Fig. 24). This consists of irregular roundish cells, and there is no indication of the tubular method of ingrowth characteristic of the modern

1 Scott and Maslen ('07), Pl. XIII, Fig. 20.

2 Brongniart ('81), Pl. II, Fig. I, and Pl. V, Fig. 3.

${ }^{3}$ Renault ('79), Pl. XVII, Fig. I5.

${ }^{4}$ D. H. S., 1802 and 1803 . 
Gymnosperm prothallus. ${ }^{1}$ At one side the valves of the shell (which are not represented in the drawing) are slightly opened, and the appearance suggests that the prothallus is emerging from the seed. It is highly probable, however, that this appearance is purely accidental.

In the case of one seed, ${ }^{2}$ in which the nucellus and megaspore are poorly preserved, a number of rather opaque, reticulately-marked bodies are seen scattered in the shell cavity. They are irregularly oval in shape, and measurements of three of the largest showed that the average size was about $77 \mu$ by $5^{8} \mu$. In another section ${ }^{3}$ similar bodies are seen embedded in the ill-preserved sarcotestal wing. It is just possible that these objects may be pollen-grains, but it is far more probable that they are foreign bodies.

\section{Histological Details.}

\section{A. The Sclerotesta.}

There is considerable variation in the thickness of the sclerotesta in different sections. This probably indicates that under the name Mitrospermum compressum we are including a group of related species. ${ }^{4}$

The cells making up the sclerotesta are somewhat elongated in the longitudinal direction, and polygonal in transverse section, the radial diameter being the greatest (Pl. XXXVIII, Fig. 1I). They have thick walls which in some cases are distinctly pitted (Pl. XXXIX, Fig. 25). The outer cells of the sclerotesta are larger than the inner, which are commonly rounder and more thin-walled. The larger cells, when seen in transverse section, may be about $100 \mu$ in the radial direction, and less than half this width in the tangential direction.

\section{B. The Sarcotesta.}

The surface of the sclerotesta is irregular, whether seen in transverse or longitudinal section, and a variable number of small, roundish, thinwalled cells separate it from the large outer cells of the sarcotesta (Pl. XXXVIII, Figs. I 3 and I6, i.c.). These thin-walled cells constitute the inner layer of the sarcotesta, and form the main part of the wing tissue (P1. XXXVIII, Fig. I2). When, as occasionally happens, the wing is cut longitudinally in the principal plane, each of the thin-walled cells is seen to be longer than it is broad, and to have a sinuous outline.

The large outer cells of the sarcotesta (Pl. XXXVIII, Figs. I3-I6, m.c.) usually form a layer one cell thick. Sometimes two or three cells are seen, but probably this is, in most cases, due to the obliqueness of the section.

1 Sokolowa ('91).

${ }^{2}$ M., R. 953 (5).

${ }^{3}$ U. C. L., S. 42 .

4 Dr. Scott suggests that a seed met with in his slides 2249 and $225^{\circ}$ (two sections from the same seed), and 2259 , may represent a distinct type. The sclerotesta is unusually thick, and the distinction between sclerotesta and sarcotesta not very sharp. 


\section{Agnes Arber.-On the Structure of the Palaeozoic Seed}

The cells may be empty, or filled with carbonized contents. They vary in size; and may, in extreme cases, exceed $500 \mu$ in length, but less than half that length is more usual. In transverse sections they measure about Ico $\mu$ in a direction tangential to the seed surface, and $50 \mu$ in the direction at right angles to this. In cases, however, where they are particularly large, they may measure as much as $200-280 \mu$ in the tangential direction. ${ }^{1}$ These measurements are taken from the part of the sarcotesta which clothes the shell. The outer large cells of the wing are generally somewhat smaller. The irregularity in size of these cells in different specimens, or even in different parts of the same specimen, is very striking (cf. P1. XXXVIII, Figs. I4 and 15). In certain cases, in which only a few of these cells are preserved, they are much swollen, and stand up freely from the surface of the shell. Altogether the appearance and behaviour of this layer suggests that the cells may have been muilage cells, analogous to those met with in the surface layers of the testa of many modern seeds, and that the irregularity in size may have been due to the varying amount of water which the mucilage had taken up before fossilization. Mucilage cells are markedly characteristic of the testas of Palaeozoic seeds of the Lagenostoma group (Lagenostoma, Conostoma, and Physostoma). ${ }^{2}$

Although the mucilage cells of Mitrospermum compressum usually appear to form the outermost layer of the sarcotesta, in more than one case there is a tissue external to them, consisting of small cells radially arranged (P1. XXXVIII, Fig. I3, o.c.). The fact that this layer is usually absent may be accounted for by the nature of the mucilage cells beneath. The swelling of the latter would cause an inelastic outer layer to crack and peel off. This would be somewhat analogous to the case of Conostoma oblongum, mentioned by Oliver, ${ }^{2}$ in which ' the common outside membrane of the very conspicuous palisade-cells of the testa is sometimes found "blown off", as though a number of these cells had emitted a quantity of mucilage'.

\section{The Seed-Base.}

Sections cut in the principal plane do not show such a sharp distinction between the elements of the sclerotesta and sarcotesta in the region below the two branch bundles (P1. XXXIX, Fig. 26, $b$ ) as in the rest of the seed. ${ }^{3}$ The sclerotesta here tends to become thinner-walled. The histological distinction between the two layers of the integument seems, however, to be variable in this part of the seed, for, though almost lost in certain sections, it is clear in others. Many cells with carbonized contents whose appearance suggests secretory cells are found in the seed-base (Pl. XXXIX, Fig. 30). There are occasional indications of an absciss layer in the hilary region. ${ }^{4}$

\footnotetext{
1 Royal Holloway College Collection, 35 I (9), and U. C. L., S. 50.

2 Oliver ('09), p. Iı. $\quad{ }_{3}$ Cf. Trigonocarpus. Scott and Maslen ('07), p. Ior.

${ }^{4}$ e. g. U. C. L., S. 65 .
} 


\section{The Vascular Tissue.}

The main supply bundle is usually represented only by tracheides. The expansion, in which it terminates below the base of the nucellus, consists of short reticulate elements (Pl. XXXIX, Fig. 29). In the basal part of the two branch bundles, however, some elongated, thin-walled elements are preserved below the tracheides. This tissue is probably phloem (ph. in Pl. XXXIX, Fig. 27). In the same section from which the figure just mentioned was drawn, two small elements with loosely spiral thickenings occur in one place on the lower side of the xylem (P1. XXXIX, Fig. 28; cf. also Fig. 26). They are about $6 \mu$ wide, and are succeeded by larger elements $10 \mu$ to $18 \mu$ wide, which are reticulate or closely spiral. The phloem is not preserved in the part of the bundle where they occur. The small elements have the characters of protoxylem, and thus the xylem of the branch bundles, at least in the lower part, would seem to have been centripetal in development. I have not met with any case of recognizable phloem in the branch bundles, after they have emerged from the shell, and curved upwards towards the micropyle. The most striking feature of the strands in this part of their course is the extreme flattening which they undergo in the principal plane of the seed, so that the bundle is better described as a tracheal plate. A transverse section in Dr. Scott's Collection ${ }^{1}$ shows one of the bundles as a chain of tracheides, twenty elements long in the plane of flattening, but only from one to three elements wide (Pl. XXXVIII, Fig. 20).

\section{Nomenclature.}

\section{A. Specific Name.}

In his original description of the seed under discussion, Williamson ${ }^{2}$ wrote, 'All the specimens agree in giving to this species much of the general dimensions and contour of the Cardiocarpum acutum of Lindley and Hutton, and of the $C$. Lindleyi of Mr. Carruthers, excepting that the latter observer describes his seeds as having a central longitudinal ridge, which my specimens certainly have not. Since these differences exist, it may be well to distinguish my type under the name of Cardiocarpon compressum.' It seems, however, that Williamson was mistaken in entirely denying the existence of a 'central longitudinal ridge', since many transverse sections which seem undoubtedly to belong to his type show a slight median ridge on the surface of each valve in the secondary plane (Text-fig. 2, C, and Pl. XXXVII, Fig. 10). In fact one of Williamson's type sections ${ }^{3}$ shows a distinct indication of a ridge, though this is rather minimized in his drawing of it. ${ }^{4}$

\footnotetext{
1 D. H. S. 2428 .

3 W. I 409 .
}

2 Williamson ('77), p. 259.

4 Williamson ('77), P1. XV, Fig. I24. 
The ridge, unlike that in Cardiocarfum acutum, ${ }^{1}$ only extended a certain distance up the shell and then died out. There is a section ${ }^{2}$ from Oldham in the Williamson Collection, which is referred in the MS. catalogue to Cardiocarpon anomalum, but which is in reality a most characteristic example of his C.compressum. It is a transverse section showing a wellmarked median ridge (Text-Fig. 2, C). It was probably this ridge which deterred Williamson from referring the section to $C$. compressum. The attribution to $C$. anomalum is a curious one, since all the other sections in the Collection, referred by Williamson to Carruthers' species C. anomalum, ${ }^{3}$ have proved to be Lepidocarpons. ${ }^{4}$

A large number of seed impressions of the Cardiocarpon type from Devonian and Carboniferous rocks have been figured by various authors, ${ }^{5}$ but none of them can with certainty be identified with Mitrospermum compressum.

\section{B. Generic Name.}

Brongniart's original description of the genus Cardiocarpon ${ }^{6}$ dealt only with external characters, and was somewhat vague. It ran as follows :-

'Cardiocarpon. Fruits comprimés, lenticulaires, cordiformes ou réniformes, terminés par une pointe peu aiguë.' 7

Since Brongniart's time various seeds, which he would probably have included in the genus Cardiocarpon, have been distributed into several newer genera, e.g. Samaropsis, Cordaicarpus, Cyclocarpus, \&c. A critical discussion of these genera, which are distinguished by slight differences in external form, has been published by Kidston, ${ }^{8}$ who concludes that it is advisable tentatively to retain Brongniart's generic name Cardiocarpon for the whole assemblage of these seeds.

Bertrand $^{9}$ has recently published a fresh description of the genus, founded on a re-examination of the silicified seeds previously studied by Brongniart and Renault, in which he discusses internal as well as external characters.

On comparing the structure of Mitrospermum compressum, as outlined in the preceding sections of this paper, with the generic characters enumerated by Bertrand for Cardiocarpus, we find that they fail to agree in one important point, namely, the type of vascular system. Bertrand restricts the use of the name Cardiocarpus to forms in which the hilo-chalazal bundle emits its

${ }^{1}$ Lindley and Hutton ('31), P1. LXXVI.

${ }^{3}$ Carruthers ('72).

${ }^{2}$ W. 1417 .

${ }^{5}$ Dawson ('71), Newberry ('73), Andrews ('75), Kidston ('94), \&c.

${ }^{6}$ The name has been used by different writers in the forms :-Cardiocarpon [Brongniart ('28), Williamson ('77)], Cardiocarpus [Brongniart ('81), Bertrand ('08)], and Cardiocarpum [Lindley and Hutton ('31)]. Compare Scott and Maslen ('07), footnote to p. 90.
${ }^{7}$ Brongniart ('28).
${ }^{8}$ Kidston ('94), p. 263.
${ }^{9}$ Bertrand $\left({ }^{\prime} 08^{2}\right)$. 
two branches before entering the shell. These two branches remain outside the shell throughout their entire course. He contrasts this type of vascular system with that of Rhabdocarpus, ${ }^{1}$ in which the main supply bundle passes unbranched through the shell. The two lateral bundles arise from the chalazal vascular plate, and immediately run down again through the shell, forming an acute angle with the main bundle. Bertrand names them 'faisceaux récurrents'. On emerging from the shell, they curve upwards and follow the same course as the bundles of Cardiocarpus. Brongniart's Cardiocarpus nummularis and $C$. temuis have the rhabdocarpic type of vascular symmetry, and hence are removed from Cardiocarpus and placed in Cyclocarpus. ${ }^{2}$

In Mitrospermum compressum the vascular system ${ }^{3}$ is intermediate between that characteristic of Rhabdocarpus and of Taxospermum. ${ }^{4}$ In the latter the branch bundles, as in Rhabdocarpus, arise from the chalazal vascular mass, but they follow the fioor of the shell cavity, and on reaching the flanks traverse the shell obliquely from below upwards.

Since the seed described in this paper cannot strictly be referred to Cardiocarpus (in Bertrand's sense), or to any of the related genera, it seems advisable to distinguish it by a new generic name. I suggest that Mitrospermum might be used in allusion to the form of the seed-base.

Mitrosfermum, gen. nov.

The characters of the genus are at present those of the only known species :-

\section{Mitrospermum compressum (Will.).}

I877. Cardiocarpon compressum, Will. W. C. Williamson, On the Organization of the Fossil Plants of the Coal Measures, Pt. VIII, p. 279.

Bilaterally symmetrical seed, flattened in the plane of symmetry. As usually preserved, the integument consists of a sclerotesta of thick-walled cells, enclosed in a more delicate sarcotesta, which extends into a wing in the principal plane. An outer layer of large mucilage cells is the most conspicuous feature of the sarcotesta. In the best preserved specimens, in addition to the parts of the integument just described, two other layers can be recognized, namely, a thin-walled tissue lining the sclerotesta, and a small-celled layer clothing the mucilage cells of the sarcotesta. The main vascular bundle enters the hilum, and passes through the sclerotesta without branching. Below the base of the nucellus, it gives off two strands in the principal plane, which are at first horizontal, but soon dip slightly downwards and outwards, traversing the sclerotesta in an oblique direction.

1 Bertrand $\left(97^{4}\right)$.
2 Bertrand ('08 ${ }^{2}$ ).

4 Bertrand ( $\left.07^{1}\right)$.
${ }^{3}$ See p. 497. 
When these branches emerge into the sarcotesta they are separated by almost the whole width of the seed-base. They turn upwards, and pass to the micropyle, keeping close to the sclerotesta throughout their course.

Localities:- South Lancashire Coalfield:-Oldham (original locality); Shore, Littleborough (abundant); Dulesgate; Hough Hill, Stalybridge.

Horizon: Lower Coal Measures.

\section{The Attribution to Cordaites.}

The present investigation has thrown no fresh light on the problemto what plants do seeds of the Cardiocarpus type belong? It may, however, be well in conclusion briefly to review the evidence on this point as it stands at present.

In 1872 Carruthers ${ }^{1}$ figured two species of Cardiocarpon, C. Lindleyi, Carr., and $C$. anomalum, Carr., attached to twigs, which he suggested belonged to an extinct Gymnosperm of the Dadoxylon type, or, as we should now say, to one of the Cordaitales.

Grand'Eury ${ }^{2}$ in 1877 pointed out that a variety of seeds known as Cardiocarpus are found associated with Cordaites in such a way as to render their identity with this genus very probable. For example, at Chazotte there are rocks filled exclusively with Cordaites accompanied by numerous Cardiocarpus seeds. Grand'Eury was also fortunately able to adduce more direct evidence. He found catkin-like inflorescences in actual organic continuity with branches bearing Cordaitean leaves, and in some cases these inflorescences contained seeds. The seeds varied in size in different specimens, and those which were best developed were recognizable as belonging to the cardiocarpic type. ${ }^{3}$

The next great advance in our knowledge of the Cordaitean fructification was due to Renault, ${ }^{4}$ who in 1879 published an account of the internal structure of the male and female catkins, illustrated by figures which have now become quite familiar. ${ }^{5}$ The female catkins were, however, much younger than those whose superficial features had been described by Grand'Eury, and were not sufficiently advanced in development to make it possible to identify the contained seeds with any of the numerous mature seeds, known only as detached specimens.

We may conclude that the work of Carruthers, Grand'Eury, and Renault, has established the fact that Cordaites bore seeds of the cardiocarpic type, using the word in a broad sense. Further than this, we find that there is some evidence from association to show that certain species of Cardiocarpus are definitely connected with certain species of Cordaites.

\footnotetext{
1 Carruthers ('72). ${ }^{2}$ Grand'Eury ('77).

8 e. g. the seeds of Cordaites nobilis, see Grand'Eury ('77), P1. XXVI, Fig. 9.

${ }^{4}$ Renault ('79). $\quad{ }^{5}$ Scott ('08), vol. ii, Figs. 193 and 194.
} 
Kidston, ${ }^{1}$ for instance, points out that Cardiocarpon Lindleyi is almost invariably found associated with Cordaites principalis. We are confronted, however, with the curious fact that there seem to be many more species of Cardiocarpon than of Cordaites. A few years ago Grand'Eury ${ }^{2}$ wrote, 'On a institué au moins cinq fois plus d'espèces de graines que de feuilles de Cordaites.' As an example he mentions that, associated with leaves identified with, or closely similar to, Cordaites palmaeformis, Göpp., five species of seeds are found-in the Franco-Belgian basin, Cardiocarpus Lindleyi, Carr., C. Pitcairniae, Lind., C. cormutus, Daw., and in the Loire basin, Samaropsis fuitans, Daw., and S. forensis, Gr. Dawson ${ }^{3}$ had previously noticed a similar disproportion between the small number of species of Cordaitean leaves, and the numerous species of seeds, occurring in the Canadian rocks with which he was concerned. Oliver ${ }^{4}$ has drawn attention to a precisely analogous difficulty in the case of the Lagenostoma group of seeds. He writes, 'One petrified seed (L. Lomaxii), and at least three impressions, superficially in agreement with the seeds of the Lagenostoma group, have been referred to the frond-type Sphenopteris. We are still left with Physostoma, L. ovoides, and the Conostomas, all petrifactions from the same group, and-excepting for Heterangium-there are no species of Sphenopteris yet separated from Lyginodendron by anatomical characters to which they could be assigned.' In the case of Cordaites, Grand'Eury's explanation is that evolution in this group has proceeded principally in the direction of changes in the reproductive organs, the vegetative structure remaining unaltered owing to uniformity of climate and conditions. It is easy, however, to take an exaggerated view of the uniformity of anatomical structure within these groups. It is likely that in the future a rigorous analysis of the anatomical characters of the Lyginodendreae, and of the Cordaitales, will reveal the existence of many more species, distinguishable on vegetative grounds, than those we know at present. In the case of the Cordaitales this analysis has already begun, and the work of Scott and Maslen ${ }^{5}$ on the subject is bringing to light many new anatomical types. On the other hand, it is possible that there may actually be some truth in the idea that there is a disproportion between the number of so-called Cordaitean seeds, and the number of species recognizable by their vegetative characters. Sorne of these seeds may perhaps prove to belong to other groups. Until 1905 no case was known in which seeds of the Platysperm type could be definitely attributed to any other plant than Cordaites. In that year, however, seeds with bilateral symmetry were discovered attached to two Pteridosperms, Aneimites ${ }^{6}$ and Pecopteris Pluckeneti. ${ }^{7}$ The notion that every member of the Platyspermeae was necessarily a Cordaitean seed, was thus discredited.

1 Kidston ('86).

4 Oliver ('09), p. in I.
${ }^{2}$ Grand'Eury ('05 $\left.{ }^{2}\right)$.

${ }^{5}$ Scott and Maslen ('10). s Dawson ('91).

${ }^{6}$ White ('05). ${ }^{7}$ Grand'Eury $\left({ }^{\prime} 05^{1}\right)$. 
The particular seed with which we have been concerned in this paper, Mitrospermum compressum, is always found unattached, and the question of its attribution must be left open until further evidence is forthcoming.

\section{REFERENCES.}

Andrews, E. B. ('75) : Description of Fossil Plants from the Lower Carboniferous Strata. Geol. Survey of Ohio, vol. ii : Geol. and Palaeontol, pt. ii : Palaeontology, I875.

Arber, Agnes ('10): A Note on Cardiocarpon compressum, Will. Proc. Camb. Phil. Soc., vol. xv, pt. v, p. $393,1910$.

Bertrand, C. E. ('0 $\left.07^{1}\right)$ : Les caractéristiques du genre Taxospermum de Brongniart. Bull. de la Soc. Bot. de France, t. liv, p. 2 I 3 , I907.

p. $389,1907$. p. $45^{2}, 1907$.

$\left({ }^{\prime} 07^{4}\right)$ : Les caractéristiques du genre Rhabdocarpus d'après les préparations de la collection B. Renault. Ibid., t. liv, p. 654 , 1907 .

Ibid., t. 1 , p. 326,1908 .

$\left({ }^{\prime} 08^{2}\right)$ : Les caractéristiques du genre Cardiocarpus d'après les graines silicifiées étudiées par Ad. Brongniart et B. Renault. Ibid., t. lv, p. 391, I908.

t. $1 v$, p. 454,1908 .

Brongniart, A. ('28): Prodrome d'une histoire des végétaux fossiles. Paris, I828.

('74): Études sur les graines fossiles trouvées à l'état silicifié dans le terrain houiller de Saint-Étienne. Ann. Sci. Nat., Bot., t. xx, p. 234, I874. ('81) : Recherches sur les graines fossiles silicifiées. Paris, I88I.

Carruthers, W. ('72): Notes on some Fossil Plants. Geol. Mag., Dec. I, vol. ix, p. r, 1872.

Dawson, J. W. ('71): The Fossil Plants of the Devonian and Upper Silurian Formations of Canada. Geol. Survey of Canada, I871.

('91): On New Plants from the Erian and Carboniferous, and on the Characters and Affinities of Palaeozoic Gymnosperms. Canadian Record of Science, vol. iv (1890I89r), I89r.

Grand'Eury, F. C. ('77) : Mémoire sur la flore carbonifère du Département de la Loire. Mémoires de l'Académie des Sciences, t. Ixxxiv, Paris, 1877 .

$\left({ }^{\prime} 05^{1}\right)$ : Sur les graines trouvées attachées au Pecopteris Pluckeneti, Schlot. Comptes Rendus, t. cxl, p. 920,1905 . $\left({ }^{\prime} 05^{2}\right)$ : Sur les Rhabdocarpus, les graines et l'évolution des Cordaïtées. Comptes Rendus, t. cxl, p. 995.

Kinston, R. ('86) : Notes on some Fossil Plants collected by Mr. R. Dunlop, Airdrie, from the Lanarkshire Coalfield. Trans. Geol. Soc. Glasgow, vol. viii, p. 47, ı 886.

('94) : On some New Species of Fossil Plants from the Lower Carboniferous Rocks of Scotland. Proc. Roy. Phys. Soc. Edinburgh, vol. xii, I 894 .

Lindley, J., and Hutton, W. ('31): The Fossil Flora of Great Britain, vol. i, London, I83I-3.

Newberry, J. S. ('73) : Descriptions of Fossil Plants from the Coal Measures of Ohio. Geol. Survey of Ohio, vol. i: Geol. and Palaeontology, pt. ii : Palaeontology, I873.

Oliver, F. W. ('03): The Ovules of the Older Gymnosperms. Annals of Bot., vol. xvii, p. 45 I, r 903. (04): On the Structure and Affinities of Stephanospermum, Brongn. Trans. Linn. Soc. Lond., Botany, vol. vi, ser. 2, p. 361, 1904. 

Annals of Botany.
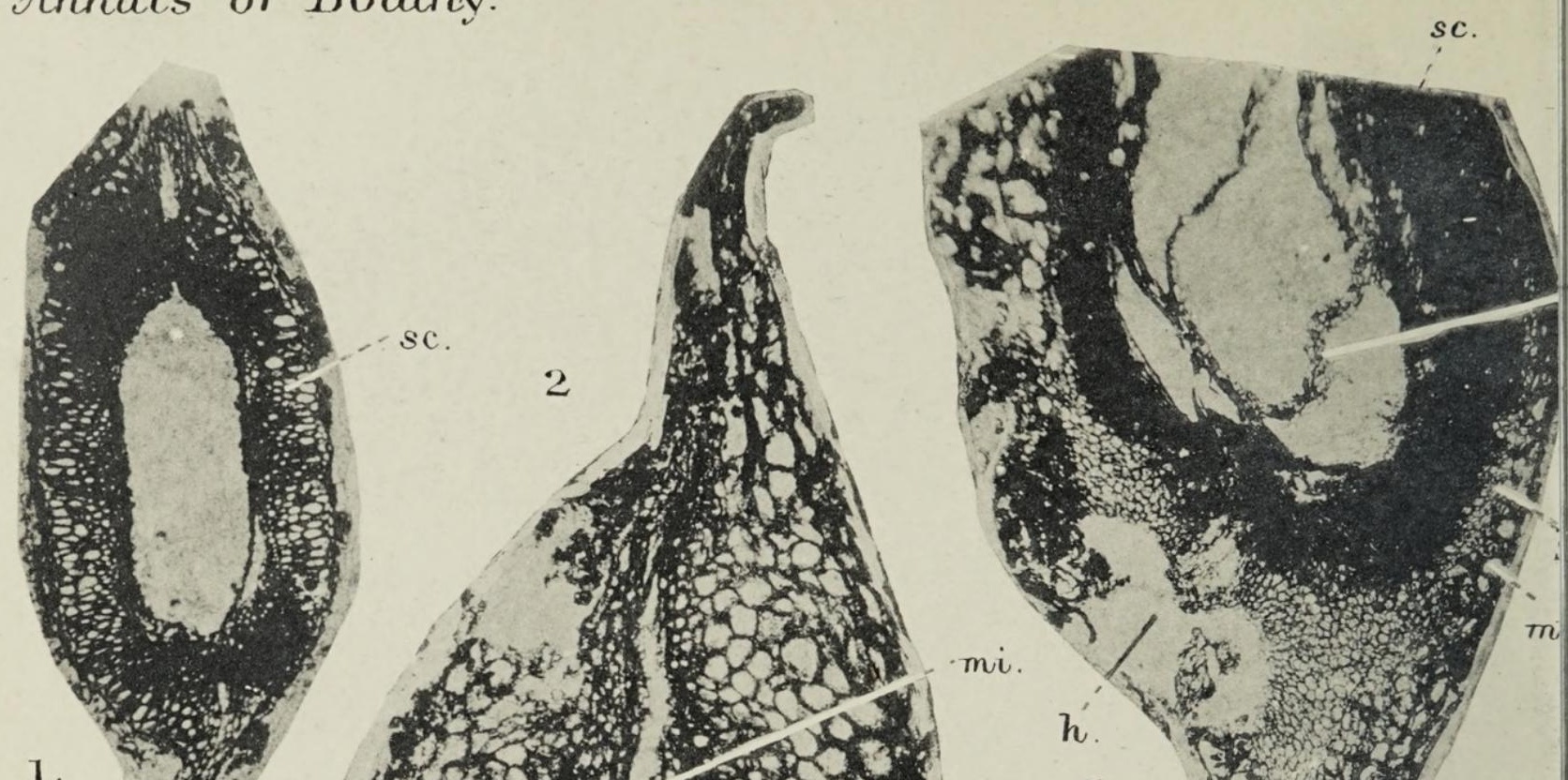

4.

1.
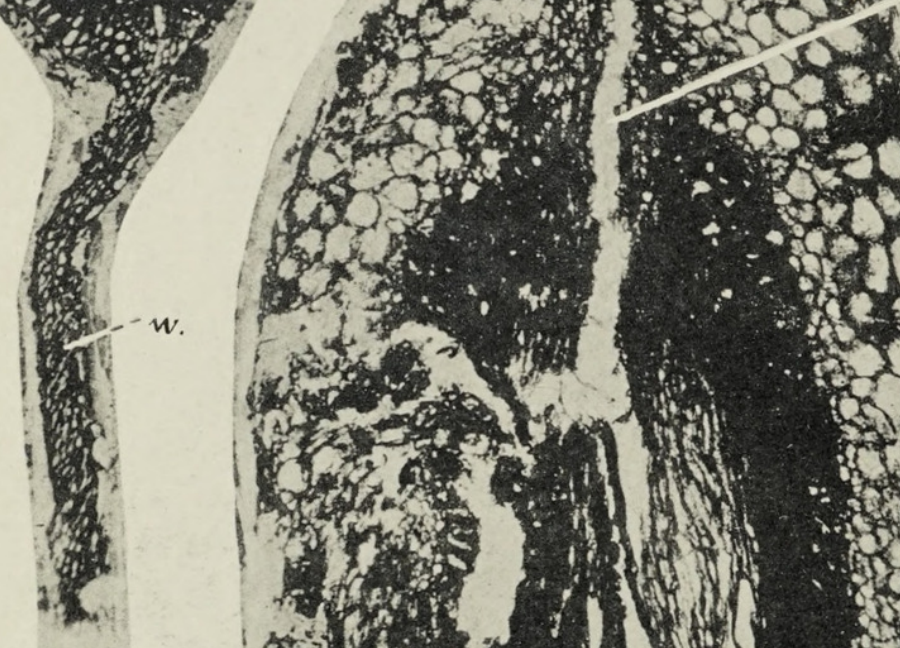

\section{3}

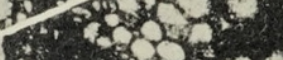

$\therefore \therefore 23=1$

ats
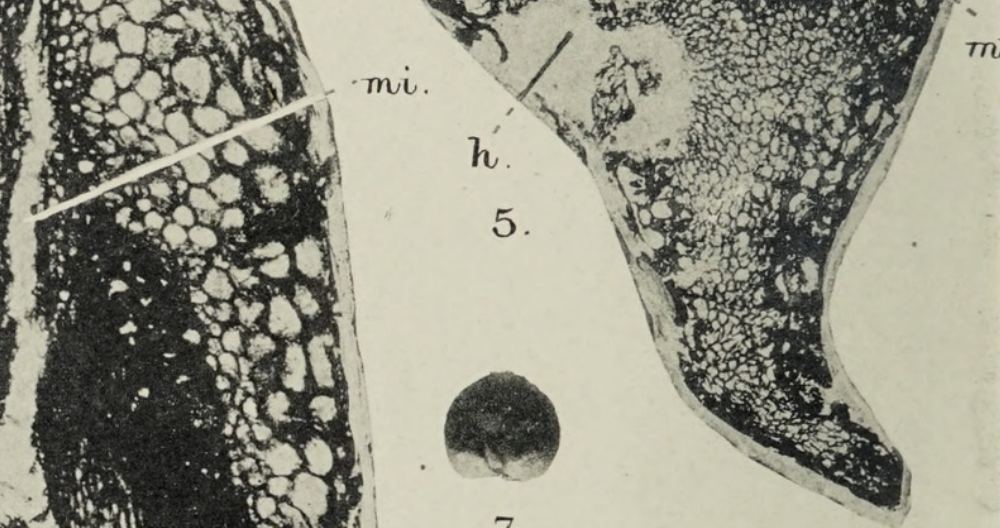

(1)
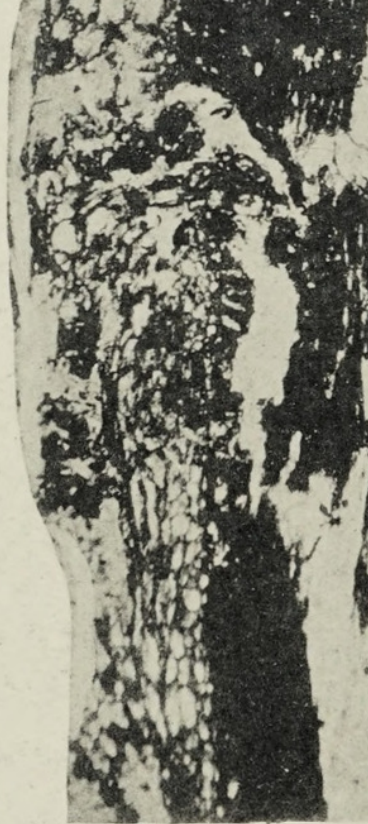

sc iff.

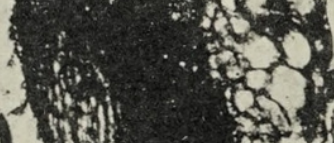

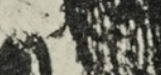
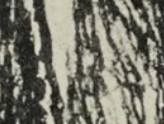

- 1
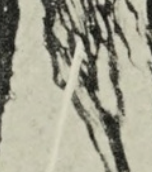

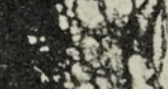
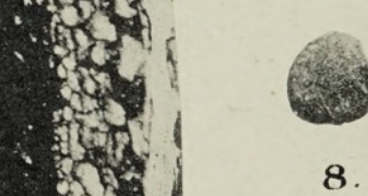

(n)

4.)

ain

ing

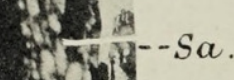

s.

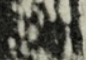

(t)

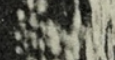

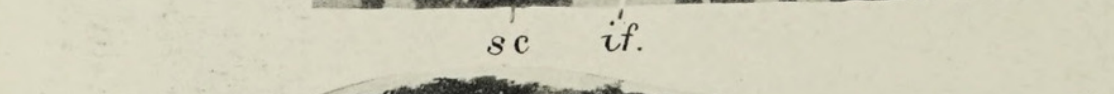

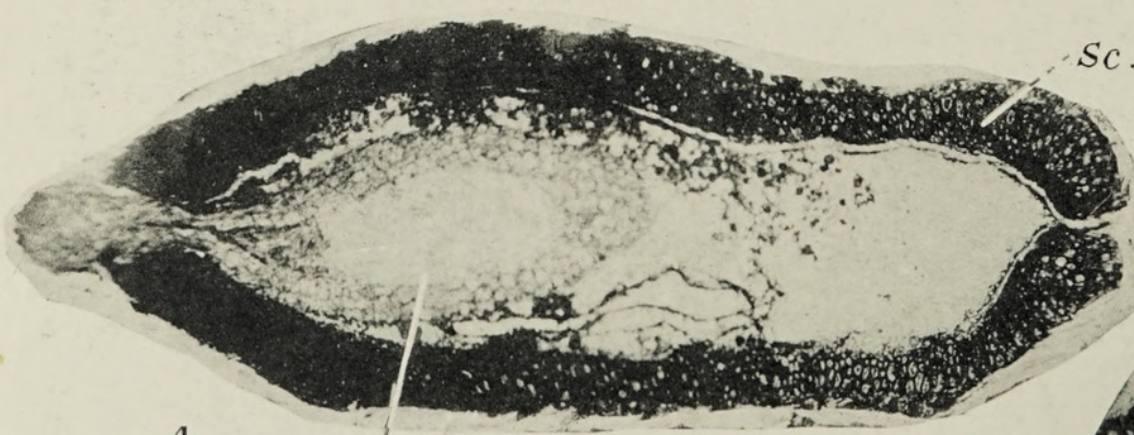

4

Stig.

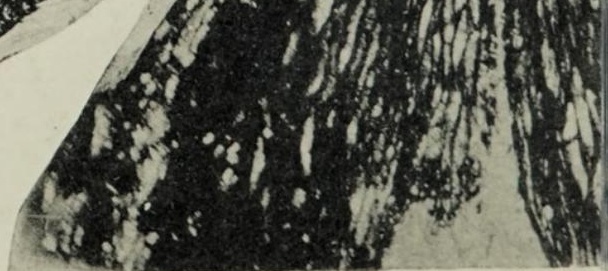


Vol,XXIV.PL.XXXVII.

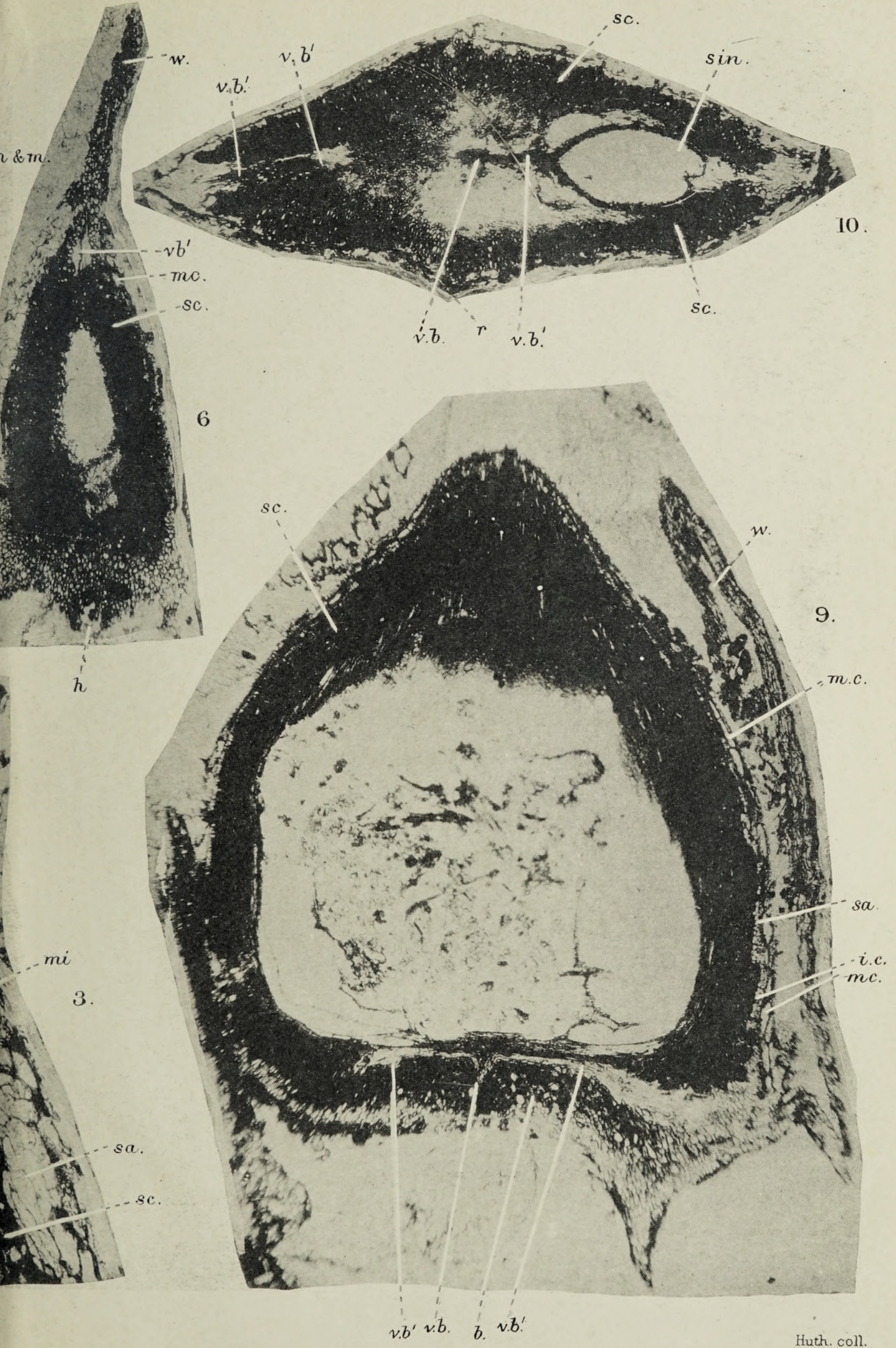




Anniats of Botany,
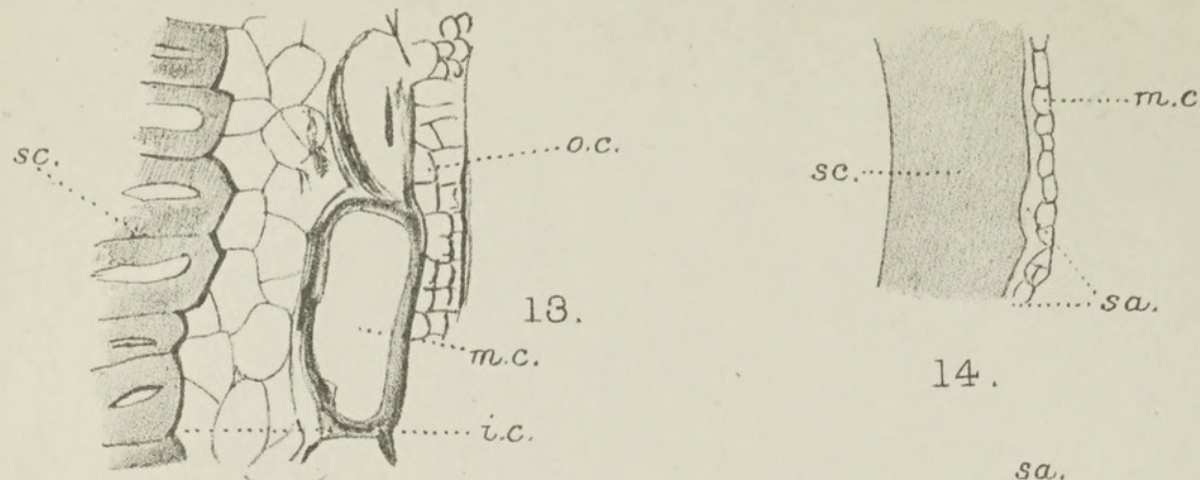

\section{4.}
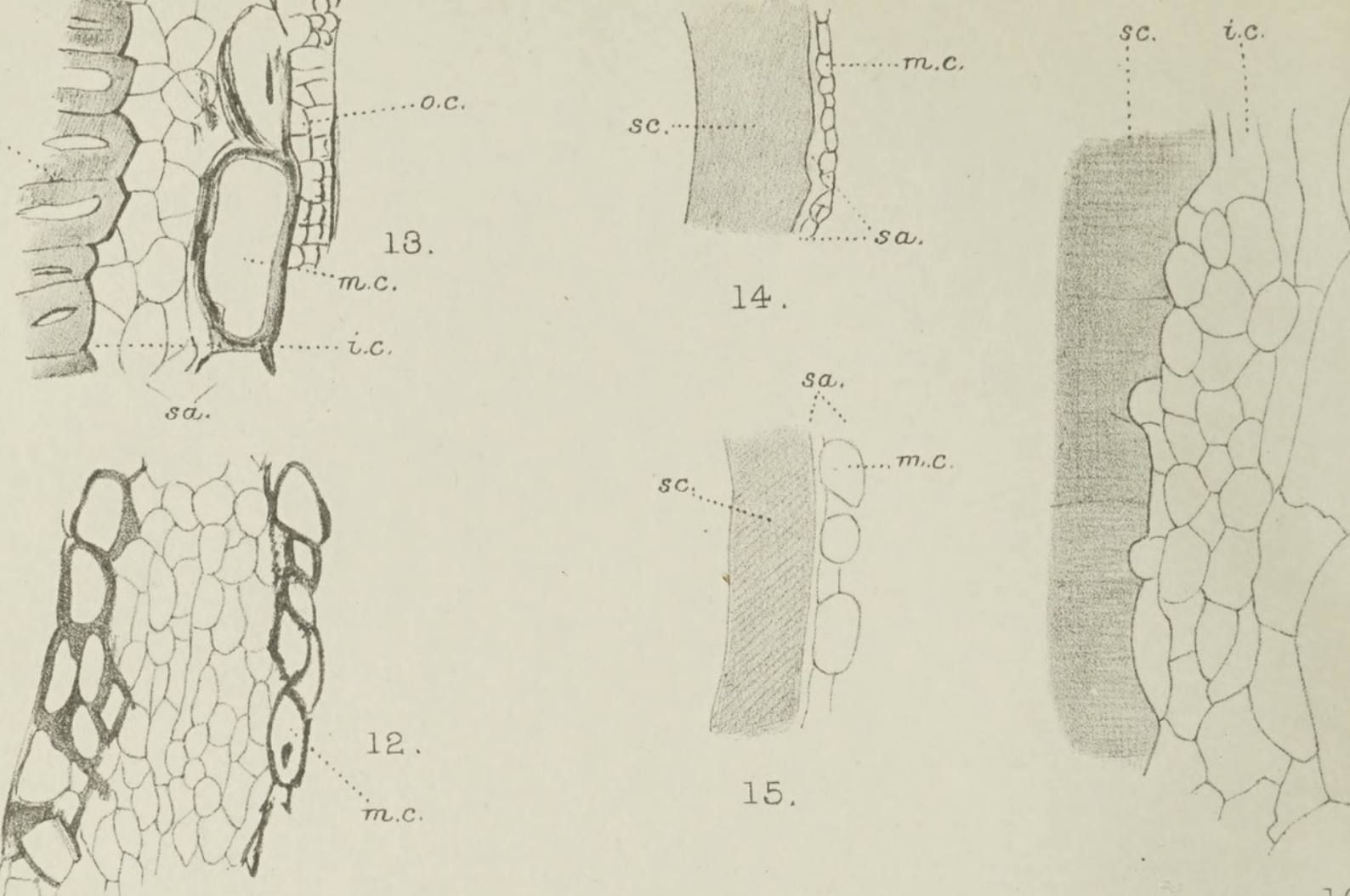

15.

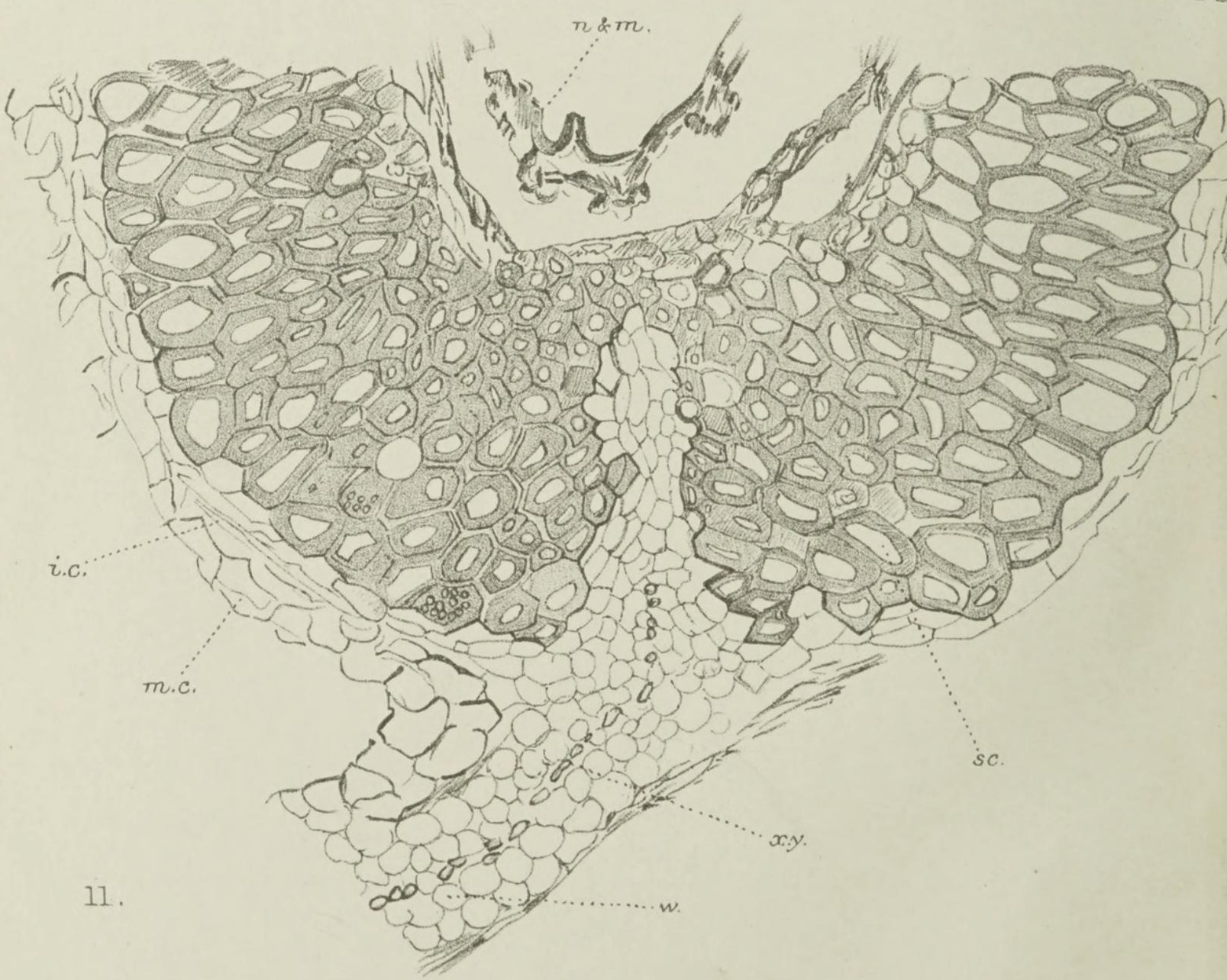




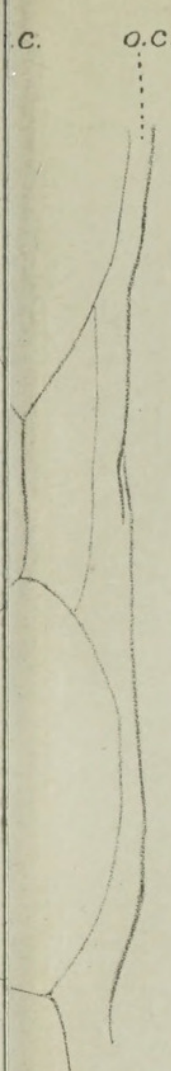

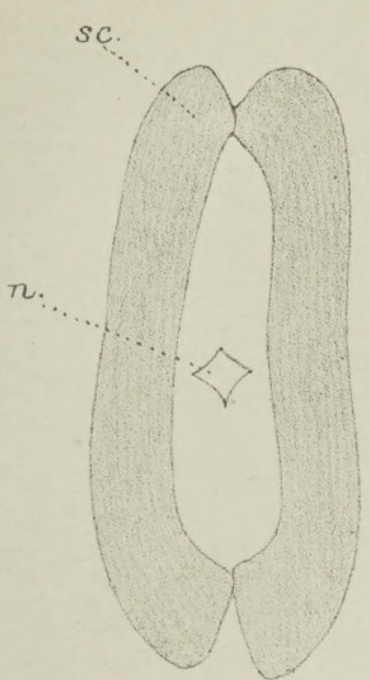

17.

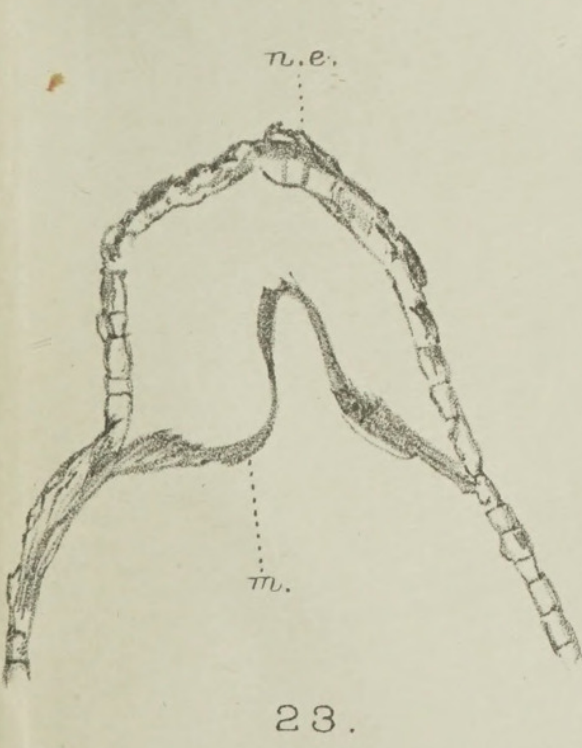

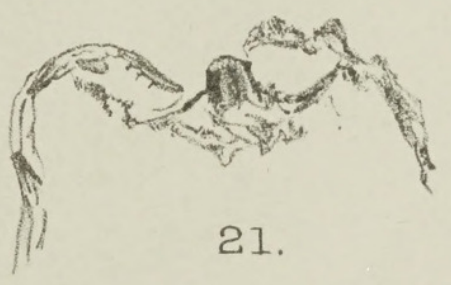

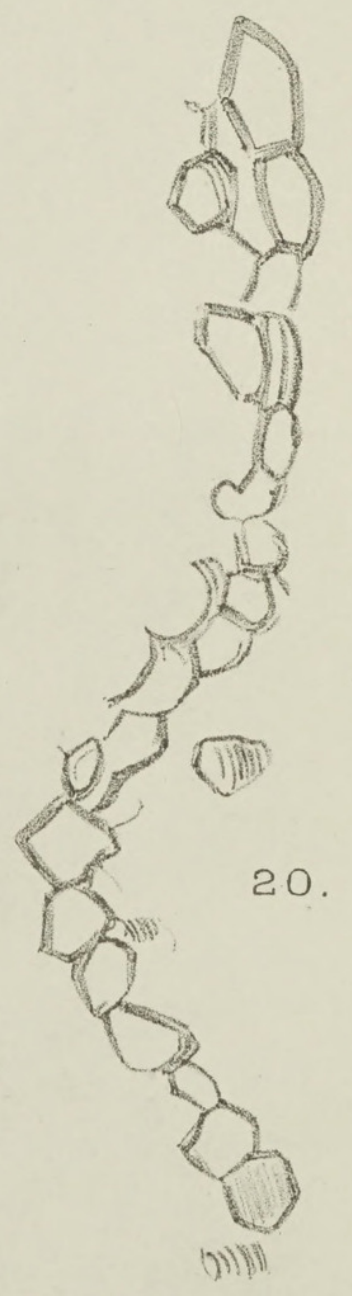

tap. n.c. n.e.

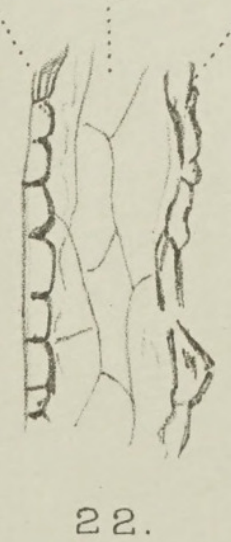

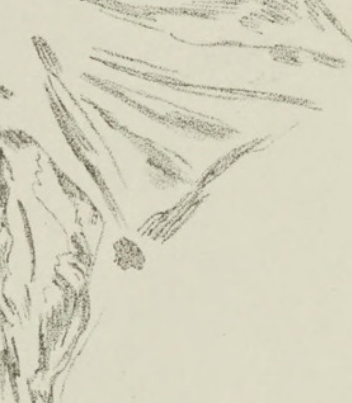





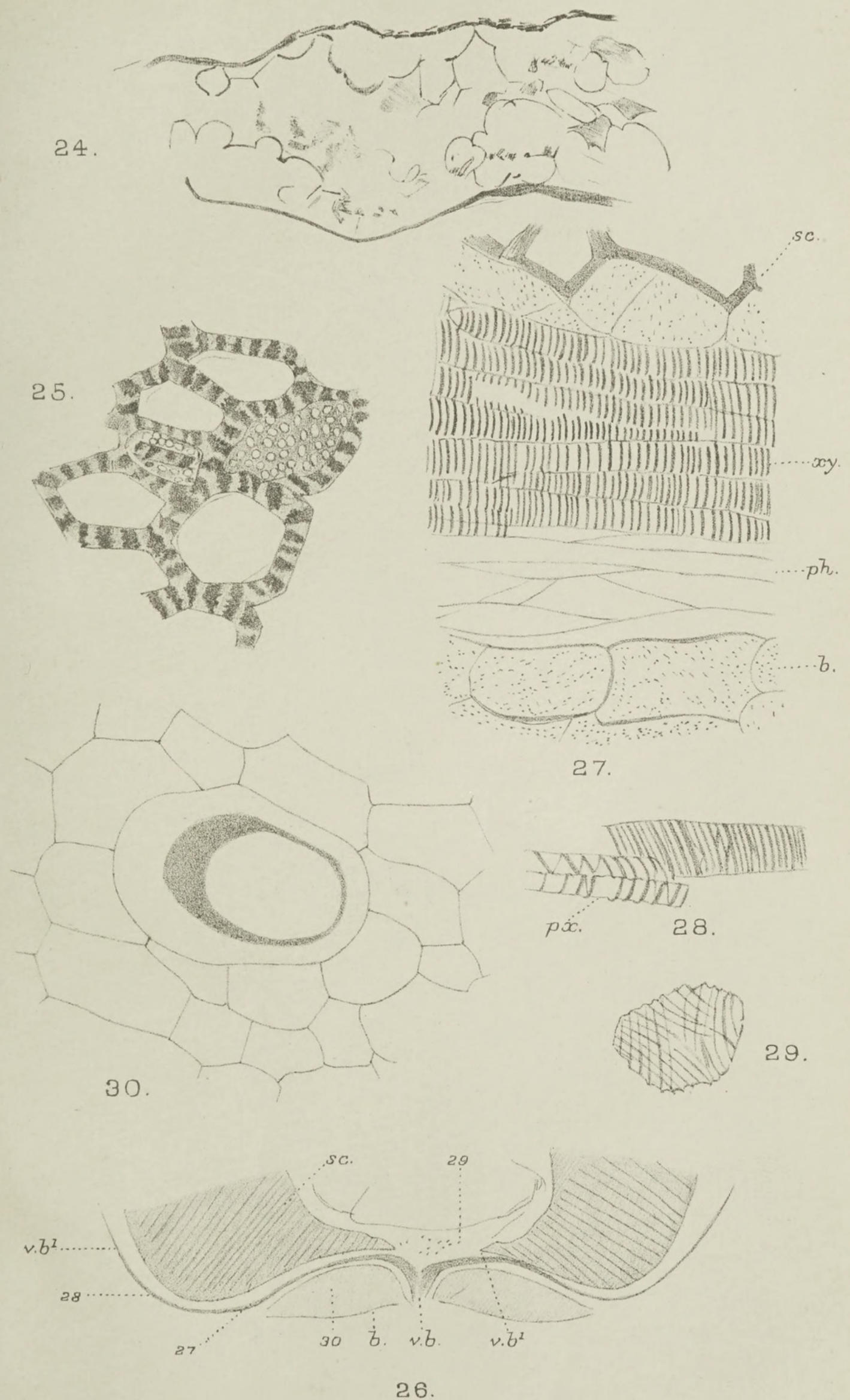



Oliver, F. W.('09): On Physostoma elegans, Will., an Archaic Type of Seed from the Palaeozoic Rocks. Annals of Bot., vol. xxiii, p. 73, I909.

Oliver, F. W., and ScotT, D. H. ('04) : On the Structure of the Palaeozoic Seed Lagenostoma Lomaxi. Phil. Trans. Roy. Soc. Lond., ser. B, vol. cxcvii, p. 193, I904.

Renault, B. ('79): Structure comparée de quelques tiges de la flore carbonifère. Nouvelles Archives du Muséum. Paris, 1879 .

ScotT, D. H. ('01): On the Structure and Affinities of Fossil Plants from the Palaeozoic Rocks. IV. The Seed-like Fructifications of Lepidocarpon. Phil. Trans. Roy. Soc. Lond., ser. B, vol. cxciv, p. 29I, I90I.

('08). Studies in Fossil Botany. London, vol. i, I908, and vol. ii, I909.

Scott, D. H., and Maslen, A. J. ('07): The Structure of the Palaeozoic Seeds Trigonocarpus Parkinsoni, Brongniart, and Trigonocarpus Oliveri, sp. nov. Pt. I. Annals of Bot., vol. xxi, p. 89,1907 .

Note. Annals of Bot., vol. xxiv, p. 236 , 19 ro.

('10): On Mesoxylon, a new Genus of Cordaitales. Preliminary

Sokolowa, C. ('91) : Naissance de l'endosperme dans le sac embryonnaire de quelques Gymno-
spermes. Bull. de la Soc. Imp. des Sci. Nat. de Moscou, p. 446 (N.S. vol. iv for I890),

Sokolowa, C. ('91) : Naissance de l'endosperme dans le sac embryonnaire de quelques Gymno-
spermes. Bull. de la Soc. Imp. des Sci. Nat. de Moscou, p. 446 (N.S. vol. iv for I 890 ), I $89 \mathrm{I}$.

White, D. ('05): The Seeds of Aneimites. Smithsonian Misc. Coll., vol. xlvii, pt. 3, 1905.

Williamson, W. C. ('77): On the Organization of the Fossil Plants of the Coal Measures, Pt. VIII. Phil. Trans. Roy. Soc. Lond., vol. 167, pt. I, p. $213,1877$.

\section{EXPLANATION OF PLATES XXXVII-XXXIX.}

Illustrating Mrs. Arber's paper on Mitrospermum compressum (Will.).

The following abbreviations are used:-

W. = Williamson Collection, British Museum of Natural History; D. H. S. = Dr. Scott's Collection; U.C. L., S. and R. = University College Collection, London; Wat., A. = Mr. D. M. S. Watson's Collection; M., R. = University of Manchester Collection.

\section{PLATE XXXVII.}

Figs. I-6, 9, I0, photographs by W. Tams; Figs. 7 and 8, photographs by E. A. N. Arber.

Fig. I. Transverse section, probably near apex of seed, showing sclerotesta (sc.), and wing (w.), the latter preserved on one side only. U. C. L., S. 48 (Shore). $\times 20$ circa.

Fig. 2. Longitudinal section in secondary plane (i. e. plane at right angles to plane of flattening, (see p. 493) passing through the micropyle (mi.). This section is remarkable for the great development of the sarcotesta (sa.) and inner flesh (i.f.). sc. $=$ sclerotesta. U. C. L., S. 70 (Shore). $\times 33$ circa.

Fig. 3. Longitudinal section of another seed cut in the same plane as that shown in Fig. 2. The micropyle $(m i$. $)$ is more widely open, and the sarcotesta $(s a$.$) less developed. s c .=$ sclerotesta. U. C. L., S. 37 (Shore). $\times 46$ circa.

Fig. 4. Transverse section of a decorticated sclerotesta (sc.), showing a stigmarian rootlet (stig.) wedging the valves apart. U. C. L., S. 45 (Dulesgate). $\times$ I $_{5}$ circa.

Fig. 5. Base of oblique longitudinal section passing through the hilum (h.). sa. = sarcotesta; $s c .=$ sclerotesta $; n$. and $m .=$ nucellus and megaspore ; m.c. mucilage cells of sarcotesta. U. C. L., S. $60 a$ (Shore). $\times 2$ I circa. 


\section{Agnes Arber.-On the Structure of the Palaeozoic Seed}

Fig. 6. Obliquely transverse section, passing through the hilum $(h$.$) on one side, and one wing$ $(w$.$) on the other. s c_{0}=$ sclerotesta $; m . c .=$ mucilage cells of sarcotesta $; v . b .^{\prime}=$ branch vascular bundle. U. C. L., S. 67 (Shore). $\times 22$ circa.

Figs. 7 and 8. Two seeds, or casts, described in Williamson's manuscript catalogue as 'Possibly a nucleus of some of the Sammaropsid forms of Lesquereux'. W. I427 (Little Hutton, near Peel, Delph, Lancashire). $\times 1 \frac{1}{5}$ circa.

Fig. 9. Longitudinal section in the principal plane (or plane of flattening), showing the origin of the branch vascular bundles $\left(v . b_{.^{\prime}}\right)$ from the main bundle $\left(v . b_{.}\right)$. The wing (w.) is partly preserved on the right-hand side. $b_{0}=$ seed base with large secretory cells $; s c .=$ sclerotesta $; s a .=$ sarcotesta, showing very clearly the division into $m . c_{0}=$ mucilage cells, and i.c. = smaller inner cells. U. C. L., S. 65 (Shore). $\times 20$ circa.

Fig. 10. Transverse section close to the base. On the right the section passes through a sinus ( $\sin$.), but on the left, as it is somewhat oblique, it dips into the sclerotesta (sc.) below the sinus. On the right the branch bundle $\left(v . b .^{\prime}\right)$ is seen passing off from the main bundle, on the left the branch bundle $\left(v . b_{0^{\prime}}\right)$ is cut further out. $r=$ median ridge of sclerotesta. U. C. L., S. 43 (Hough Hill, Stalybridge). $\quad \times 26$ circa.

\section{PLATE XXXVIII.}

\section{DRAWINGS.}

Fig. I1. One end of a transverse section, showing the junction of the two valves of the sclerotesta $(s c$.$) and base of the sarcotestal wing (w$.$) . The vascular elements (x y$.$) form a row down the middle$ of the wing. The large outer cells of the sarcotesta (m.c.) are poorly preserved. i.c. $=$ inner cells of sarcotesta $; n$. and $m$. = nucellus and megaspore. U. C. L., S. 46 (Shore). $\times 90$.

Fig. 12. Slightly oblique transverse section of part of sarcotestal wing. $m . c_{.}=$mucilage cells. U. C. L., S. 57 (Hough Hill). $\times 90$.

Fig. I3. Edge of a transverse section through sclerotesta (sc.) and sarcotesta (sa.), showing inner cells of sarcotesta (i.c.), mucilage cells (m.c.), and small outermost cells (o.c.). U. C. L., S. $5^{\text {I }}$ (Dulesgate). $\times$ I50.

Fig. I 4. Transverse section of sclerotesta (sc.) and sarcotesta (sa.) to show the proportion which the size of the unswollen mucilage cells $(m . c$.) bears to the thickness of the sclerotesta. U. C. L., S. 5 I (Dulesgate). $\times 28$.

Fig. I5. Transverse section of sclerotesta (sc.) and sarcotesta (sa.) to show the relative size to which the mucilage cells (m.c.) may attain in extreme cases (cf. Fig. I4). U. C. L., S. 50 (Shore). $\times 28$.

Fig. I6. Small part of a slightly oblique longitudinal section, showing the edge of the sclerotesta (sc.) and the sarcotesta (sa.). $i . c_{0}=$ small inner cells of sarcotesta ; m. $c_{0}=$ mucilage cells $; o . c_{0}=$ membrane probably representing the remains of the small outer cells of the sarcotesta. Wat., A. II 3 (Dulesgate). $\times$ I 55 .

Fig. I7. Transverse section of sclerotesta $(s c$.$) and nucellus (\boldsymbol{n}$.$) , probably from near the top of$ a seed. Wat., A. 248 (Shore). $\quad \times 28$.

Fig. I8. Nucellus from Fig. I 7 enlarged. Possibly the section passes through the rather flat roof of the pollen-chamber. Wat., A 248 (Shore). $\times 387$.

Fig. 19. Transverse section of a contracted and carbonized nucellus, probably near its apex, to show the four-angled form. D. H. S. 2259 (Shore). $\times 4^{2}$.

Fig. 20. Tracheides of branch vascular bundle from transverse section of seed, showing flattening and extension in the principal plane. [The position of the bundle can be understood by reference to Text-fig. 2, C.] D. H.S. 2428 (Shore). $\times 375$.

Fig. 2I. Apex of nucellus in longitudinal section, showing obliquely cut pollen-chamber (?). U. C. L., S. 47 (Shore). $\times 46$.

Fig. 22. Longitudinal section of a small part of the nucellus, from a section in which it is unusually well-preserved, showing nucellar epidermis (n.e.), thin-walled nucellar tissue (n.c.), and nucellar tapetum (tap.). U. C. L., S. $3^{6}$ (Shore). $\times \mathbf{1}_{55}$.

Fig. 23. Nucellar epidermis (n.e.) (or possibly nucellar tapetum) enclosing megaspore membrane $(\mathrm{m}$.) (or possibly carbonized tapetum), from a transverse section. D. H. S. 2428 (Shore). $\times 90$. 


\section{Mitrospermum compressum (Will.).}

\section{PLATE XXXIX.}

\section{DRAWINGS.}

Fig. 24. Part of a transverse section of a seed, showing the megaspore membrane (or carbonized tapetum) enclosing a tissue which may be a prothallus. D. H.S. 1803 (Dulesgate). $\times 57$ circa.

Fig. 25. Thick-walled, pitted elements of the sclerotesta in transverse section. U. C. L., S. 53 (Shore). $\times 244$ circa.

Fig. 26. Base of a longitudinal section cut in the principal plane. The numbers indicate the position of the details drawn in Figs. 27, 28, 29, 30. v. $b .=$ main vascular bundle ; v. $b .^{\prime}=$ branch bundle; $s c .=$ sclerotesta $; b .=$ tissue of seed-base below branch bundles. U. C. L., R. $60 c$ (Shore). $\times 8 \frac{1}{2}$ circa.

Fig. 27. Branch bundle cut longitudinally in its nearly horizontal course through the sclerotesta. (See ' 27 ' in Fig. 26.) sc. $=$ sclerotesta $; x y .=x y l e m ; h_{0}=$ phloem $; \quad b_{0}=$ tissue of seed-base. U. C. L., R. $60 c$ (Shore). $\quad \times 400$ circa.

Fig. 28. Small part of the bundle drawn in Fig. 27, but further out, at the point where it is emerging from the shell and turning upwards (see ' 28 ' in Fig. 26). Protoxylem occurs on the lower side of the bundle. U. C. L., R. $60 c$ (Shore). $\times 400$ circa.

Fig. 29. Short reticulate tracheide from just below the nucellus (see ' 29 ' in Fig. 26). U. C. L., R. $60 c$ (Shore). $\times 400$ circa.

Fig. 30 . Secretory cell and surrounding cells from seed-base tissue below the branch bundles (see ' 30 ' in Fig. 26). U. C.L, R. 60 c. $\times 400$ circa. 


\section{$2 \mathrm{BHL}$ Biodiversity Heritage Library}

Arber, Agnes Robertson. 1910. "On the structure of the palaeozoic seed Mitrospermum compressum (Will.)." Annals of botany 24, 491-509. https://doi.org/10.1093/oxfordjournals.aob.a089283.

View This Item Online: https://www.biodiversitylibrary.org/item/262605

DOI: https://doi.org/10.1093/oxfordjournals.aob.a089283

Permalink: https://www.biodiversitylibrary.org/partpdf/319791

\section{Holding Institution}

New York Botanical Garden, LuEsther T. Mertz Library

\section{Sponsored by}

BHL-SIL-FEDLINK

\section{Copyright \& Reuse}

Copyright Status: Public domain. The BHL considers that this work is no longer under copyright protection.

This document was created from content at the Biodiversity Heritage Library, the world's largest open access digital library for biodiversity literature and archives. Visit BHL at https://www.biodiversitylibrary.org. 